\title{
Antecedents of Consumers' Purchase Intention towards Organic Food: Integration of Theory of Planned Behavior and Protection Motivation Theory
}

\author{
Suk Min Pang ${ }^{1, *}$, Booi Chen Tan ${ }^{1}$ and Teck Chai Lau ${ }^{2}$ \\ 1 Faculty of Management, Multimedia University, Persiaran Multimedia, Cyberjaya 63100, Selangor, Malaysia; \\ bctan@mmu.edu.my \\ 2 Southampton Business School, University of Southampton Malaysia, Kota Ilmu Educity Iskandar, \\ Iskandar Puteri 79200, Johor, Malaysia; t.c.lau@soton.ac.uk \\ * Correspondence: smin.pang@gmail.com
}

Citation: Pang, S.M.; Tan, B.C.; Lau, T.C. Antecedents of Consumers'

Purchase Intention towards Organic Food: Integration of Theory of Planned Behavior and Protection Motivation Theory. Sustainability 2021, 13, 5218. https://doi.org/ $10.3390 /$ su13095218

Academic Editor: Riccardo Testa

Received: 10 March 2021

Accepted: 1 May 2021

Published: 7 May 2021

Publisher's Note: MDPI stays neutral with regard to jurisdictional claims in published maps and institutional affiliations.

Copyright: (c) 2021 by the authors. Licensee MDPI, Basel, Switzerland. This article is an open access article distributed under the terms and conditions of the Creative Commons Attribution (CC BY) license (https:// creativecommons.org/licenses/by/ $4.0 /)$.

\begin{abstract}
Before consequences of climate change continue to intensify and increasingly affect the entire planet, immediate action must be taken. For instance, adopt the pro-environmental behaviors such as purchase of organic food to minimize the harmful human-caused impacts to the environment. This paper aims to determine the factors that influence the purchase intention of organic food in Malaysia by applying the theory of planned behavior and the protection motivation theory. A total of 300 questionnaires were collected and PLS-SEM was employed to test the structural relationships. Consequences of climate change and health threats were not the primary concerns among Malaysians when deciding whether to purchase organic food. Results show that perceived vulnerability, response efficacy, self-efficacy, subjective norm, and attitude affect purchase intention towards organic food. Consumers were more likely to have positive attitude towards organic food when they have adequate information on vulnerability of a threat and its consequences. The findings provide insights on the antecedents and outcomes of purchase intention towards organic food particularly in Malaysia. Although predictive power of perceived factors such as perceived rewards and perceived efficacy have been extensively researched in the past, there are limited studies that integrate both theories that simultaneously investigate antecedents of consumers' purchase intention towards organic food.
\end{abstract}

Keywords: climate change; attitudes; mediator; organic food; purchase intention; theory of planned behavior; protection motivation theory; response efficacy; subjective norm; Malaysia

\section{Introduction}

In recent years, socially responsible consumption increased as demands of socially and environmentally responsible consumers have been on the rise. Socially responsible consumption includes recycling and use of products based on their environmental impact [1]. Recently, interest in green products grew rapidly due to the increase in consumer demand and companies' supply, as well as the increase in the number of research publications in the context of organic food. Moreover, consumers nowadays are trying to make sound food choices and choose organic food over its alternatives as it helps climate change by releasing fewer greenhouse gases and reducing pollution from synthetic fertilizers. This is in line with United Nations Sustainable Development Goal 13 which aims to address the needs of developing countries to take urgent action to combat and adapt to climate change, as well as invest in low-carbon development [2]. Nevertheless, two commonly stated reasons for the implementation of organic practices and purchasing organic food are one's environmental concern and health concern, with the latter exceeding the former in terms of importance [3].

Despite the need to adjust food preferences to organic diet, market analysis concerning Malaysian green purchase intention in the context of the four perceived factors remains 
underexplored. Although many past studies have looked into the antecedents of purchase intention towards organic food, their conclusions have not reached the consensus on the key antecedents [4-7]. Furthermore, there seems to be little research that investigates the extent to which perception from threat and coping appraisal process will affect purchase intention. To fill the gap in understanding purchase intention towards organic food, this study aims to assess the perception related to both the threat and coping appraisal, as well as perceived rewards and costs.

People nowadays tend to be more aware of their environmental and health issues, which led to the practice of organic agriculture. Increased interest in organic food among consumers and more academic research in this field have caught the attention of academic community. This study could provide valuable insights for marketers, policymakers, and future researchers as it examines how individuals perceive climate change and what factors influence consumers' intention to purchase organic food. These would enable the related parties to respond effectively as a society. Furthermore, the gap in relevant knowledge can be minimized by understanding and examining the mediating effects of attitude on the factors that influence purchase intention towards organic food among Malaysian consumers, particularly when there are limited studies that test the mediating effect of attitude. In a nutshell, this study could contribute greatly and significantly to existing literature as well as the community.

\section{Literature Review}

\subsection{An Overview of the Organic Food Sector in Malaysia}

Climate change has worsened and the demand for action to slow down the global warming is increasingly urgent. For instance, the rise in global temperature, decreased sea ice, rise in sea level, and warmer oceans have proven that rapid climate change is happening. To fight against the negative consequences of climate change, pro-environmental behaviors such as adoption of organic farming must be promoted to help generate a more sustainable production system and a better future.

Consumers nowadays tend to "think green" and have greater willingness to pay extra for organic food products. The organic food market worldwide is expected to rise and grow at over $16 \%$ by the year 2020 [8]. Malaysian consumers are becoming more concerned of their health and are slowly changing their preference to organic food. The increasing demand from local markets has also stimulated the growth of the Malaysian organic products. The value of organic food production in Malaysia is targeted at RM 200 million by the year 2025 to fulfil the demand for organic food and export market [9]. However, the demand of organic food is still considered low, and Malaysia currently heavily depends on imported organic food to meet the local demand as $60 \%$ to $90 \%$ of organic food products are imported [10]. In Asia, out of the 6.1 million hectares of organic farming land in 2017, only $0.01 \%$ or 603 hectares of organic farming land is managed by 119 producers in Malaysia [11]. This shows that at least in Malaysia, the organic food sector is still in its infancy.

\subsection{Definition of Organic Food and Its Practices}

In the early 2000s, organic food is defined as one of the green products that are organically grown and manufactured through green technology and do not cause any severe environmental hazards. "Organic food" is a term frequently used in the literature, but up to now there is no agreement and consensus on the universally accepted definition of organic food [12]. It could be said that organic food are the goods produced by an agricultural system that avoids the use of synthetic chemicals and complies with organic standards to achieve the three main goals of sustainability: social, economic, and environment sustainability. 


\subsection{Theoretical Foundation}

\subsubsection{Theory of Planned Behavior (TPB)}

The theory of planned behaviors (TPB) is an extension of the theory of reasoned action (TRA). TPB is useful for empirical studies to discover factors underlying pro-environmental behaviors [13] and the extended theory also received wide support in recent literature. In Ajzen's TPB, three constructs-namely, an individual's attitude towards the behavior, subjective norm, and the perceived behavioral control-will determine an individual's behavioral intention, which subsequently will lead to the adoption of a behavior. Theoretically, an individual's behavior indirectly depends on the attitude, subjective norm, and perceived behavioral control, with behavioral intention acting as the mediating factor.

\subsubsection{Protection Motivation Theory (PMT)}

Rogers [14] protection motivation theory (PMT) is an extension of the health belief model (HBM) and is commonly used as the theoretical foundation for the study of an individual's protective behaviors. PMT is a theory that deals with motivation for behavioral change. The basic assumption of PMT is that when individuals make a pro-environmental decision, they will consider both the current and new behaviors in terms of costs and benefits [15]. Although PMT was initially developed for general health problems [16], the model is adequately broad to be applied in any situation that involves predicting the protective health behavior [17-19].

\subsubsection{Integration of Theory of Planned Behavior and Protection Motivation Theory}

Although PMT has been widely applied in health behavioral studies [20], its application in organic food is still rather limited. One of the rationales for the integration of the theory of planned behavior and protection motivation theory is that although TPB can provide comprehensible explanations on how attitudes, perceived behavioral control, and subjective norm could yield organic food consumption, the theory does not explain the potential motivators governing the consumption of organic food in terms of uncertainty and risk. An individual is motivated to carry out an action to reduce the risks if they experience and face both the environmental and health risks [21]. TPB and PMT also have some similarities in nature [22], which make them a good approach for theory integration. For instance, protection motivation in PMT is similar to intention in TPB, while TPB's perceived behavioral control is similar to PMT's self-efficacy. These similarity and logics show that integrating TPB and PMT models would enhance the study of consumers' purchase intention towards organic food.

\subsection{Purchase Intention towards Organic Food}

According to Nguyen, et al. [23], behavioral intention is the possibility that an individual will engage in a specific behavior. Satisfying and fulfilling different consumers' needs are the easiest way to encourage consumers to purchase the product and raise profits. Consumers' expectations not only focus on prior experiences but are also reflected in the current product evaluation and experiences [24]. When a product meets consumer's expectation and needs, the consumer will be satisfied and be more willing to purchase the product. Thus, a consumer is said to have purchase intention towards organic food when there is a high probability that they are willing to pay and purchase organic food over its alternatives (i.e., conventional food) in their purchase considerations.

\subsection{Factors That Influence Consumers' Purchase Intention towards Organic Food}

\subsubsection{Perceived Threat}

A recent study by Bai, Wang, and Gong [25] suggested that perceived threat is comprised of three sub-constructs: perceived severity, perceived vulnerability, and fear. Perceived severity denotes the belief of an individual on how seriously a threat would affect their life $[22,26]$. In Gebrehiwor and Veen's study with a sample size of 240, the study found that perceived severity and response costs were the two main variables that affected 
farmers' intentions to carry out risk reducing measures [27]. The relationship between perceived severity and intention was further supported by Rainear and Christensen's study, which revealed that perceived severity was one of the strongest factors that predicted intention [28].

In this study, perceived severity can be visualized in the context of how seriously an individual perceives the environmental threat and the assessment of the adverse consequences of the threat for not consuming organic food. Perceived vulnerability assesses how personally vulnerable or susceptible individuals feel to a threat [25]. Specifically, the perceived vulnerability of this study represents an individual's assessment of whether they will be threatened if they do not take action to reduce the threat due to not consuming organic food. Fear is added to the perceived threat as an additional sub-construct because fear arousal is closely associated with threats and is used to measure the degree of possibility that a person will be affected by a threat. In this organic food context, fear can be visualized in terms of the individual's fear that they will get ill if they do not exclusively consume organic food.

\subsubsection{Perceived Rewards}

Past studies tested both the intrinsic and extrinsic rewards under perceived rewards $[29,30]$ and revealed that when one perceives they would gain more benefits by not engaging in the recommended behavior, they will have lower intentions to carry out the recommended behavior. The definition of intrinsic and extrinsic rewards in PMT is slightly different from the widely acknowledge definition in organizational behaviors studies. In the protection motivation theory, high intrinsic and extrinsic rewards from less consumption of organic food will predict less intention to purchase organic food. Intrinsic and extrinsic rewards are rarely assessed in PMT research because any reward, both intrinsic and extrinsic, linked to not performing a particular protective behavior can be rearticulated as a response cost of involving in protective behavior [31]. For instance, when an individual believes that the current practice of buying conventional food is more rewarding, they also tend to believe that the cost of buying organic food is high, hence they will continue with the current practice of buying conventional food. Nevertheless, perceived rewards that are not included in previous studies have a great impact on the threat appraisal process [32] and it is suggested that the two underutilized constructs be considered in future studies [33]. For current research, both the intrinsic and extrinsic rewards will be included and tested to address the gap by developing a full nomology of PMT to explain consumers' purchase intentions.

\subsubsection{Perceived Efficacy}

Perceived efficacy consists of two sub-constructs, namely-response efficacy and self-efficacy. Instead of reducing a threat, Scarpa and Thiene [34] defined response efficacy in terms of protection in those circumstances where an individual believed that the particular adaptive response would be helpful in protecting themselves and others from the threat. Past studies revealed that response efficacy had a positive impact on intention to adopt a behavior $[5,7,31]$. In this study, response efficacy refers to consumers' belief that the consumption of organic food should be an effective way to lessen the health and environmental threat.

Bandura's concept of perceived self-efficacy focuses on the beliefs that an individual can perform the necessary courses of action to handle the potential situations [35], provided that the individual knows their capabilities and nature. Perceived self-efficacy concept is similar to the theory of planned behavior's perceived behavioral control because perceived self-efficacy is one of the components of the perceived behavioral control concept [36]. Past studies found out that self-efficacy appears to be one of the strongest predictors of purchase intention $[19,31]$. Consumers tend to purchase a product when they think it is possible and easy for them to carry out the task. However, only the construct "self-efficacy" will be used in this study to avoid the overlap between self-efficacy and perceived behavioral control constructs. In the current study, self-efficacy can be visualized in terms of the 
individual's belief that they can reduce environmental threat if they successfully adopt organic food consumption.

\subsubsection{Perceived Cost}

Perceived cost has one sub-construct, which is the response cost. Consumers are usually not willing to purchase a product when they perceive the cost outweighs the benefits. In the protection motivation theory, response costs refer to any costs related to taking the adaptive coping response, includes both the monetary and non-monetary cost such as financial costs and effort, as well as time taken to carry out the particular action [37]. Hence, the response cost in this study does not indicate only the prices of organic food, but also in terms of convenience, products range, and adjustment in food consumption. A recent study by Aung and Chotiyaputta [38] which analyzes consumers' intention to purchase poultry product by applying PMT found out that response costs have a statistically negative effect on purchase intention, because consumers tend to reduce the barrier to purchase and have higher intention to purchase especially when they have greater knowledge on the product. Hence, response cost in this study can be visualized in term of one's belief that they will purchase organic food if the benefits of organic food outweigh the costs of purchasing.

\subsubsection{Subjective Norm}

Definition of subjective norm is provided by Aertsens, Verbeke, Mondelaers, and Huylenbroeck [39] in the early of 2000s, as the perceived social expectations or pressure from important people whether to carry out a behavior. The "important others" may include the individual's family members, spouse, relatives, close friends, colleagues, and physician. A recent study by $\mathrm{Chu}$ [40] which investigated consumers' intention to purchase organic food in China revealed that there was full mediation of attitude between subjective norm and purchase intention. Results from the study indicated that consumers would assure themselves that they are behaving responsibly in regard to their important others' expectations when they purchase organic food.

\subsubsection{Attitude}

A consumer's attitude largely depends on their knowledge about the object or behavior (cognitive component), which then influence their feelings and emotions about the object or behavior (affective component), and subsequently affects how they act in accordance with the object or behavior (behavioral component) [41]. In this study, a consumer's attitude towards organic food takes in the point of view of a consumer about the topic on organic food (cognitive component), how they feel about organic food (affective), and the action they take as a result of attitude in preventing any problem (behavioral).

\subsection{Proposed Research Framework}

Based on the theoretical and empirical literature reviewed, a research framework is proposed to study the antecedents of consumers' purchase intention towards organic food in Malaysia. Perceived severity (PS), perceived vulnerability (PV), fear (F), intrinsic rewards (IR), extrinsic rewards (ER), response efficacy (RE), self-efficacy (SE), response cost (RC), and subjective norm (SN) are independent variables. Attitude towards organic food (AT) is the mediator. On the other hand, purchase intention towards organic food (PI) is dependent variable. Figure 1 shows the proposed research framework. The hypotheses of the study are as follows:

H1. Perceived severity directly and positively influence purchase intention.

H2. Perceived vulnerability directly and positively influence purchase intention.

H3. Fear directly and positively influence purchase intention.

H4. Intrinsic rewards directly and negatively influence purchase intention. 
H5. Extrinsic rewards directly and negatively influence purchase intention.

H6. Response efficacy directly and positively influence purchase intention.

H7. Self-efficacy directly and positively influence purchase intention.

H8. Response cost directly and negatively influence purchase intention.

H9. Subjective norm directly and positively influence purchase intention.

H10. Attitude directly and positively influence purchase intention.

H11. Perceived severity indirectly and positively influence purchase intention through attitude towards organic food.

H12. Perceived vulnerability indirectly and positively influence purchase intention through attitude towards organic food.

H13. Fear indirectly and positively influence purchase intention through attitude towards organic food.

H14. Intrinsic rewards indirectly and negatively influence purchase intention through attitude towards organic food.

H15. Extrinsic rewards indirectly and negatively influence purchase intention through attitude towards organic food.

H16. Response efficacy indirectly and positively influence purchase intention through attitude towards organic food.

H17. Self-efficacy indirectly and positively influence purchase intention through attitude towards organic food.

H18. Response cost indirectly and negatively influence purchase intention through attitude towards organic food.

H19. Subjective norm indirectly and positively influence purchase intention through attitude towards organic food.

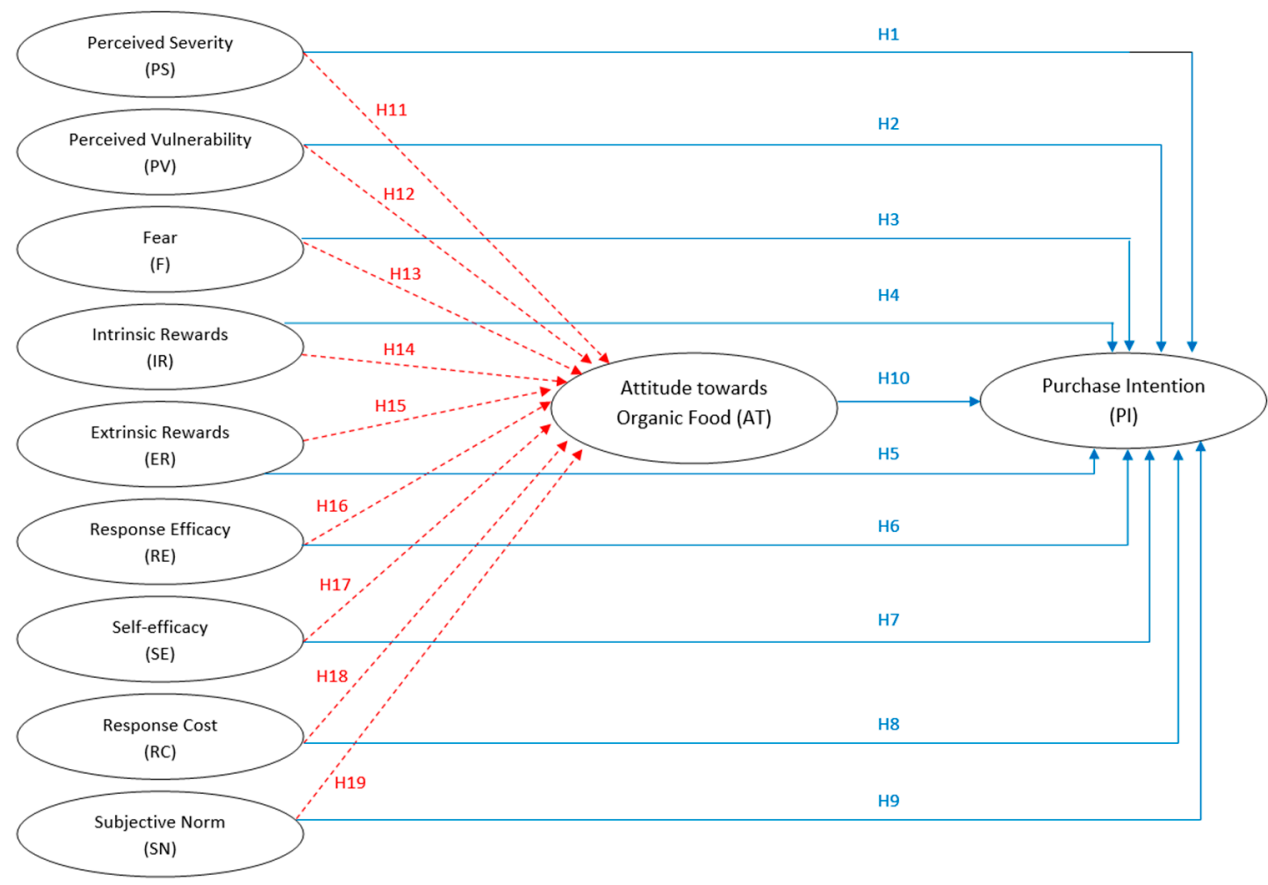

Figure 1. Proposed framework of purchase intention towards organic food. Notes: $\longrightarrow$ direct effects; $-\rightarrow$ indirect effects. 


\section{Materials and Methods}

\subsection{Measures}

Questionnaire for the eleven constructs were either adopted or adapted from previous studies that applied TPB and PMT in pro-environmental and organic food context. All the constructs were measured on a 7-point Likert scale. Other Likert scales, such as 4-point, 5-point, and 10-point are not used in this study because respondents will be forced to make a choice when they have no opinion. Larger Likert Scale will also discourage the respondents to complete the survey as there are a lot of question items for all the constructs and longer time is needed to fill up the questionnaire. This is supported by [42] that 7-point scale is commonly suggested in boosting respondents' ease of taking the survey while allowing them to express their opinion sufficiently. The four items that measured perceived severity and perceived vulnerability were adapted from Rainear and Christensen [28]; three items that measured fear were adapted from Scarpa and Thiene [34]; four items and eight items that measured intrinsic rewards and extrinsic rewards, respectively were adapted from Ibrahim and Al-Ajlouni [43] and Wu, Linn, Fu, and Sukoco [44]; three items that measured response efficacy were adapted from Ibrahim and Al-ajlouni [43]; three items that measured self-efficacy were adapted from Wang, et al. [37]; and six items that measured response cost were adapted from Ibrahim and Al-Ajlouni [43] and Scarpa and Thiene [34]. In addition, four items that measured subjective norm were adapted from Paul, Modi, and Patel [45], while three items that measured attitude and five items that measured purchase intention were adopted from the same source. The demographic variables include gender, age, marital status, the highest academic qualification, occupation, monthly income, and ethnicity. The complete list of the survey instruments was presented in Appendix A.

\subsection{Sample and Procedures}

The target population were Malaysian consumers aged 18 and above who lived in the Klang Valley. In Malaysia, about sixty percent (60\%) of the purchasing power was in the Klang Valley [46]. The survey was conducted from December 2019 to April 2020. A total of 350 copies of questionnaires were distributed face-to-face and via online survey to the targeted respondents, with 300 and 50 questionnaires, respectively. Convenience sampling was used to obtain information required as it was not possible to get sampling frame from the local authorities. In addition, the use of convenience sampling was consistent with the methods that were employed in past studies [47-51]. Following the guidelines suggested in the past [52-56], after discarding the unusable data, the useable sample size of 300 was sufficient for data analysis. Several statistical analysis techniques are employed in the study so as to test the data collected, include structural equation modelling (SEM), descriptive and correlation analysis, factor analysis, reliability analysis, and validity analysis. PLSSEM was employed to test the structural relationship of the constructs proposed in the conceptual model.

Table 1 shows the profile of the respondents in this study. Based on the data collected, male respondents slightly outnumber female respondents with 55\% and $45 \%$, respectively. The majority of the respondents are from the age group of 26-35 (57\%), followed by the age group of $18-25(24 \%)$. In terms of marital status, $65 \%$ of the respondents are single. For education level, $45 \%$ of respondents are degree holders, followed by secondary school $(23 \%)$. As for occupational level, the majority of respondents are executive officers and self-employed-with $27 \%$ and $25 \%$, respectively. In terms of monthly income, majority of the respondents (34\%) earn RM5001 and above. There was a diverse range of ethnic groups and majority are Chinese (64\%). Normality test is utilized to examine whether the dataset is modelled for normal distribution. All the constructs in this study have met the threshold suggested by Hair, Black, Babin, and Anderson [55] in terms of normality, thus the data are considered normal. 
Table 1. Respondent's Profile.

\begin{tabular}{|c|c|c|}
\hline Variable & Frequency & Percentage (\%) \\
\hline \multicolumn{3}{|l|}{ Gender } \\
\hline Male & 166 & $55 \%$ \\
\hline Female & 134 & $45 \%$ \\
\hline \multicolumn{3}{|l|}{ Age Group } \\
\hline $18-25$ & 73 & $24 \%$ \\
\hline $26-35$ & 172 & $57 \%$ \\
\hline $36-45$ & 42 & $14 \%$ \\
\hline $46-55$ & 4 & $1 \%$ \\
\hline 56 and above & 9 & $3 \%$ \\
\hline \multicolumn{3}{|l|}{ Marital Status } \\
\hline Single & 195 & $65 \%$ \\
\hline Married & 100 & $33 \%$ \\
\hline Divorced & 5 & $2 \%$ \\
\hline \multicolumn{3}{|l|}{ Education Level } \\
\hline Secondary school & 68 & $23 \%$ \\
\hline Certificate/Diploma & 51 & $17 \%$ \\
\hline Bachelor's Degree & 135 & $45 \%$ \\
\hline Postgraduate Degree & 44 & $15 \%$ \\
\hline Others & 2 & $1 \%$ \\
\hline \multicolumn{3}{|l|}{ Occupational Level } \\
\hline Self-employed & 74 & $25 \%$ \\
\hline Professional & 51 & $17 \%$ \\
\hline Manager/Senior Manager & 23 & $8 \%$ \\
\hline Executive Officer & 81 & $27 \%$ \\
\hline Housewife & 6 & $2 \%$ \\
\hline Student & 51 & $17 \%$ \\
\hline Unemployed & 5 & $2 \%$ \\
\hline Others & 9 & $3 \%$ \\
\hline \multicolumn{3}{|l|}{ Monthly Income } \\
\hline RM1500 and below & 73 & $24 \%$ \\
\hline RM1501-RM3500 & 42 & $14 \%$ \\
\hline RM3501-RM5000 & 83 & $28 \%$ \\
\hline RM5001 and above & 102 & $34 \%$ \\
\hline \multicolumn{3}{|l|}{ Ethnicity } \\
\hline Malay & 83 & $28 \%$ \\
\hline Chinese & 192 & $64 \%$ \\
\hline Indian & 23 & $8 \%$ \\
\hline Others & 2 & $1 \%$ \\
\hline
\end{tabular}

\section{Results}

\subsection{Measurement Model Assessment}

In accordance to Anderson and Gerbing's two-step approach [57], the measurement model was first assessed so as to ensure the reliability and validity of the model. The results demonstrate that all the constructs in this study has Cronbach's Alpha ranges from 0.790 to 0.948 , which implies a reliable scale $[58,59]$ and signifies that all the items measure the same concept. Composite reliability was assessed and the values were greater than 0.70 , except response cost. However, the composite reliability for response cost is close to the threshold of 0.70. Therefore, all constructs in this research study is said to have satisfactory level of reliability. Based on the findings in Table 2, the AVEs are all greater than 0.50, except response cost. However, Fornell and Larcker [60] suggested that the convergent validity of the construct is still satisfactory and adequate if AVE is less than 0.50, but composite reliability is greater than 0.60 . In this case, response cost has met the criteria mentioned with the values of composite reliability of 0.649 and AVE of 0.293 . Nevertheless, indicators 
starting from the lowest loadings should be deleted. Hence, items IR1, ER1, ER2, ER3, ER4, and RC1 were deleted due to low loadings.

Table 2. Measurement model or the constructs.

\begin{tabular}{|c|c|c|c|c|c|}
\hline $\begin{array}{l}\text { First Order Constructs } \\
\text { (after Deletion of Items) }\end{array}$ & Items & $\begin{array}{c}\text { Cronbach's } \\
\text { Alpha }\end{array}$ & Loadings & CR & AVE \\
\hline \multirow[t]{4}{*}{ Perceived Severity (PS) } & PS1 & 0.915 & 0.916 & 0.942 & 0.801 \\
\hline & PS2 & & 0.911 & & \\
\hline & PS3 & & 0.916 & & \\
\hline & PS4 & & 0.834 & & \\
\hline \multirow[t]{4}{*}{ Perceived Vulnerability (PV) } & PV1 & 0.926 & 0.862 & 0.947 & 0.818 \\
\hline & PV2 & & 0.906 & & \\
\hline & PV3 & & 0.939 & & \\
\hline & PV4 & & 0.908 & & \\
\hline \multirow[t]{3}{*}{ Fear $(\mathrm{F})$} & F1 & 0.864 & 0.854 & 0.919 & 0.791 \\
\hline & $\mathrm{F} 2$ & & 0.919 & & \\
\hline & F3 & & 0.893 & & \\
\hline \multirow[t]{3}{*}{ Intrinsic Rewards (IR) } & IR2 & 0.825 & 0.830 & 0.932 & 0.821 \\
\hline & IR3 & & 0.933 & & \\
\hline & IR4 & & 0.951 & & \\
\hline \multirow[t]{4}{*}{ Extrinsic Rewards (ER) } & ER5 & 0.876 & 0.947 & 0.983 & 0.935 \\
\hline & ER6 & & 0.978 & & \\
\hline & ER7 & & 0.971 & & \\
\hline & ER8 & & 0.972 & & \\
\hline \multirow[t]{3}{*}{ Response Efficacy (RE) } & RE1 & 0.918 & 0.910 & 0.948 & 0.859 \\
\hline & RE2 & & 0.941 & & \\
\hline & RE3 & & 0.930 & & \\
\hline \multirow[t]{3}{*}{ Self-efficacy (SE) } & SE1 & 0.893 & 0.921 & 0.933 & 0.824 \\
\hline & SE2 & & 0.929 & & \\
\hline & SE3 & & 0.873 & & \\
\hline \multirow[t]{5}{*}{ Response Cost (RC) } & $\mathrm{RC} 2$ & 0.790 & 0.820 & 0.838 & 0.511 \\
\hline & RC3 & & 0.648 & & \\
\hline & $\mathrm{RC} 4$ & & 0.734 & & \\
\hline & RC5 & & 0.690 & & \\
\hline & RC6 & & 0.670 & & \\
\hline \multirow[t]{4}{*}{ Subjective Norm (SN) } & SN1 & 0.938 & 0.930 & 0.957 & 0.847 \\
\hline & SN2 & & 0.942 & & \\
\hline & SN3 & & 0.951 & & \\
\hline & SN4 & & 0.855 & & \\
\hline \multirow[t]{3}{*}{$\begin{array}{c}\text { Attitude towards Organic } \\
\text { Food (AT) }\end{array}$} & AT1 & 0.948 & 0.957 & 0.967 & 0.907 \\
\hline & AT2 & & 0.953 & & \\
\hline & AT3 & & 0.946 & & \\
\hline \multirow[t]{5}{*}{ Purchase Intention (PI) } & PI1 & 0.944 & 0.896 & 0.957 & 0.817 \\
\hline & PI2 & & 0.888 & & \\
\hline & PI3 & & 0.883 & & \\
\hline & PI4 & & 0.928 & & \\
\hline & PI5 & & 0.924 & & \\
\hline
\end{tabular}

Note: Item IR1, ER1, ER2, ER3, ER4, and RC1 were deleted due to low loadings.

Discriminant validity was tested through Heterotrait-Monotrait ratio (HTMT). A HTMT value higher than 0.85 (HTMT0.85) [61] or HTMT value higher than 0.90 (HTMT0.90) [62] indicates there is an issue of discriminant validity. The results in Table 3 showed that all the values fulfil the criterion of HTMT0.85 and HTMT0.90. All the HTMT values were less than the stricter criterion of $\leq 0.85$ and it can be concluded that the 
respondents understood that the 11 constructs are different, thus discriminant validity has been ascertained.

Table 3. Heterotrait-Monotrait ratio of correlations (HTMT).

\begin{tabular}{|c|c|c|c|c|c|c|c|c|c|c|}
\hline Constructs & AT & ER & $\mathbf{F}$ & IR & PS & PV & PI & RC & RE & SE \\
\hline \multicolumn{11}{|l|}{$\mathrm{AT}$} \\
\hline ER & 0.122 & & & & & & & & & \\
\hline $\mathbf{F}$ & 0.451 & 0.246 & & & & & & & & \\
\hline IR & 0.076 & 0.817 & 0.171 & & & & & & & \\
\hline PS & 0.399 & 0.100 & 0.233 & 0.124 & & & & & & \\
\hline PV & 0.422 & 0.145 & 0.321 & 0.053 & 0.683 & & & & & \\
\hline PI & 0.737 & 0.161 & 0.508 & 0.143 & 0.337 & 0.341 & & & & \\
\hline RC & 0.119 & 0.331 & 0.198 & 0.280 & 0.172 & 0.232 & 0.164 & & & \\
\hline RE & 0.574 & 0.158 & 0.426 & 0.139 & 0.270 & 0.234 & 0.614 & 0.124 & & \\
\hline SE & 0.473 & 0.294 & 0.482 & 0.324 & 0.310 & 0.356 & 0.504 & 0.248 & 0.476 & \\
\hline SN & 0.501 & 0.244 & 0.521 & 0.241 & 0.150 & 0.165 & 0.553 & 0.161 & 0.431 & 0.414 \\
\hline
\end{tabular}

\subsection{Structural Model Assessment}

Evaluation of the structural model is necessary to determine the capability of the model in predicting one or more target constructs and the evaluation was done through measuring R2, f2, and Q2 values [63]. For R2, the value should be at least 0.25 [63], while for f2, value of above 0.02 indicates there is at least a small level of effect size [64]. Q2 value of larger than zero signifies that the exogenous constructs have predictive relevance for the endogenous constructs of interest [65]. In this research study, all the values achieved the required level.

\subsection{Hypothesis Testing}

Hypothesis testing was carried out to assess the plausibility of the hypothesis by using the sample data. Bootstrapping is necessary for hypothesis testing to find out the standard errors which subsequently give approximate $t$-values for significance testing of the structural path. Re-sample bootstrapping procedure was carried out by using 500 subsamples, test type of two-tailed test, and 0.05 significance level.

Figure 2 and Table 4 showed the results of the structural model. For the direct relationships, the results show that $\mathrm{H} 6, \mathrm{H} 9$, and $\mathrm{H} 10$ were supported. As hypothesized, response efficacy $(\beta=0.199, p<0.05)$, subjective norm $(\beta=0.158, p<0.05)$, and attitude towards organic food $(\beta=0.429, p<0.05)$ were found to be positively related to intention to purchase organic food. In contrast, perceived severity, perceived vulnerability, fear, intrinsic and extrinsic rewards, self-efficacy, and response cost had insignificant effect on consumers' purchase intention towards organic food. Thus, H1, H2, H3, H4, H5, H7, and H8 were not supported. 


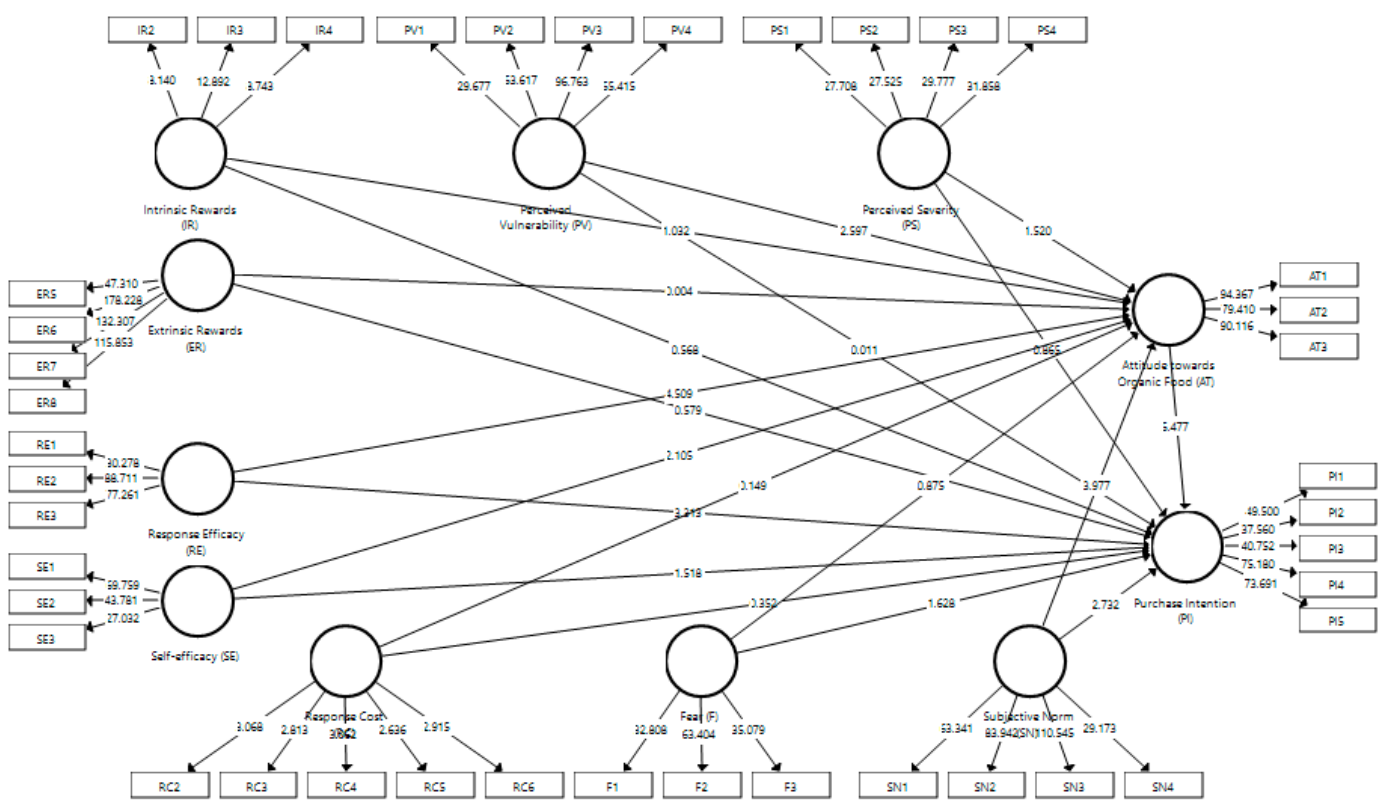

Figure 2. $t$-values for the measurement and structural model estimation.

Table 4. Results for the assessment of significance and relevance of the structural model relationships.

\begin{tabular}{cccccccc}
\hline Hypothesis & Relationship & Path Coefficient & Sample Mean (M) & Standard Error & $t$-Value & $p$-Value & Results \\
\hline H1 & PS $\rightarrow$ PI & 0.045 & 0.045 & 0.053 & 0.865 & 0.388 & Not supported \\
\hline H2 & PV $\rightarrow$ PI & 0.001 & -0.003 & 0.062 & 0.011 & 0.991 & Not supported \\
\hline H3 & F $\rightarrow$ PI & 0.090 & 0.095 & 0.056 & 1.628 & 0.104 & Not supported \\
\hline H4 & IR $\rightarrow$ PI & 0.038 & 0.039 & 0.067 & 0.568 & 0.570 & Not supported \\
\hline H5 & ER $\rightarrow$ PI & -0.038 & -0.040 & 0.066 & 0.579 & 0.563 & Not supported \\
\hline H6 & RE $\rightarrow$ PI & 0.199 & 0.193 & 0.060 & 3.313 & 0.001 & Supported \\
\hline H7 & SE $\rightarrow$ PI & 0.073 & 0.072 & 0.048 & 1.518 & 0.130 & Not supported \\
\hline H8 & RC $\rightarrow$ PI & 0.019 & 0.029 & 0.055 & 0.352 & 0.725 & Not supported \\
\hline H9 & SN $\rightarrow$ PI & 0.158 & 0.165 & 0.058 & 2.732 & 0.007 & Supported \\
\hline H10 & AT $\rightarrow$ PI & 0.429 & 0.423 & 0.078 & 5.477 & 0.000 & Supported \\
\hline H11 & PS $\rightarrow$ AT $\rightarrow$ PI & 0.042 & 0.045 & 0.029 & 1.459 & 0.145 & Not supported \\
\hline H12 & PV $\rightarrow$ AT $\rightarrow$ PI & 0.076 & 0.069 & 0.035 & 2.157 & 0.032 & Supported \\
\hline H13 & F $\rightarrow$ AT $\rightarrow$ PI & 0.027 & 0.026 & 0.028 & 0.965 & 0.335 & Not supported \\
\hline H14 & IR $\rightarrow$ AT $\rightarrow$ PI & -0.031 & -0.023 & 0.026 & 1.158 & 0.247 & Not supported \\
\hline H15 & ER $\rightarrow$ AT $\rightarrow$ PI & 0.000 & -0.004 & 0.026 & 0.004 & 0.997 & Not supported \\
\hline H16 & RE $\rightarrow$ AT $\rightarrow$ PI & 0.131 & 0.124 & 0.042 & 3.130 & 0.002 & Supported \\
\hline H17 & SE $\rightarrow$ AT $\rightarrow$ PI & 0.052 & 0.048 & 0.026 & 2.046 & 0.041 & Supported \\
\hline H18 & RC $\rightarrow$ AT $\rightarrow$ PI & -0.005 & 0.001 & 0.030 & 0.157 & 0.875 & Not supported \\
\hline H19 & SN $\rightarrow$ AT $\rightarrow$ PI & 0.108 & 0.102 & 0.029 & 3.708 & 0.000 & Supported \\
\hline & & & & & & \\
\hline
\end{tabular}

Next is the assessment of the mediation model. Perceived vulnerability $(\beta=0.0 .076$, $p<0.05)$, response efficacy $(\beta=0.131, p<0.05)$, self-efficacy $(\beta=0.052, p<0.05)$, and subjective norm $(\beta=0.108, p<0.05)$ were found out to have significant indirect effect on purchase intention via attitude towards organic food. Therefore, H12, H16, H17, and H19 were supported. On the contrary, perceived severity, fear, intrinsic and extrinsic rewards, and response cost were found to have no significant indirect effect on purchase intention. Thus, H11, H13, H14, H15, and H18 were not supported. The summary of hypotheses was presented in Table 4. 


\section{Discussion}

Global warming no doubt has caused long-lasting changes to our climate system which will have irreversible consequences if we do not take preventive action. Although the levels of carbon dioxide have fallen $5.5 \%$ to $5.7 \%$ due to the COVID-19 pandemic and travel bans, this drop of emissions is only short-term good news [66]. The emissions will return to normal once the global economy starts to recover from the pandemic. Therefore, all countries and its citizens must be on board and work together on carbon dioxide removal such as increased use of renewable energy sources and switch to organic food practices which has lower greenhouse gas emissions for crop production so as to avoid dangerous climate change. In keeping with the United Nations Sustainable Development Goals, especially Goal 13, every man jack should take urgent action to combat climate change and achieve a better as well as more sustainable future for everyone.

This study was designed to explore Malaysian consumers' purchase intentions towards organic food using two behavioral theoretical models: theory of planned behavior and protection motivation theory. Perceived threat components did not have much significant effect on purchase intention. This outcome might be attributed to the nature of the samples used. In this research, $81 \%$ of the respondents were in the age group between $18-35$ years old and this age group had fewer health issues compared to other age groups, which might lead to low tendency to protect their health and the environment through diets and purchase of organic food.

The findings also showed that response efficacy and subjective norm were strong antecedents of purchase intention, both directly and indirectly. This implied that providing efficacy-enhancing information in health and climate change message was important to encourage pro-environmental behaviors and the consumption of organic food. Messages containing strong efficacy information are tend to be persuasive and encourage pro-environmental behaviors, compared to those messages without such efficacy information [5]. When consumers received messages that have strong efficacy information and believed that purchasing organic food could reduce the health and environmental threats, they would be more likely to be convinced and thus would increase their intention to purchase organic food.

In addition, the results also indicated that consumers perceived that there were more rewards, both intrinsic and extrinsic, from purchasing conventional food. This belief inhibited the risk preventive behaviors and consumers were not likely to purchase organic food because when consumers perceive that the current practices of purchasing conventional food provide higher rewards, they would be more likely to continue the current practices and have lower intention to be involved in the recommended behaviors of organic food purchase.

Contradictory to past studies $[19,30,67,68]$ which revealed that self-efficacy was the most significant antecedent of purchase intention, no significant relationship was found between self-efficacy and purchase intention towards organic food in this study. The result may indicate that consumers thought that it was strenuous for them to be involved in the purchase of organic food. In addition, response cost was not significant on purchase intention. Costs of purchasing organic food did not increase or decrease consumers' purchase intention towards organic food. In other words, the cost of purchasing organic food might not be the most important reason for consumers when deciding whether to purchase organic food.

Green products include organic food have drawn the interest of consumers in developing countries such as China, Malaysia, Indonesia, and India [69]. Nevertheless, there is little attention given to developing countries such as Malaysia on the behavior compelling consumer's intention to purchase organic food. As compared to developed countries, the consumption of organic food is considered a new practice in developing countries. Moreover, growing yet limited literature on organic food in emerging countries such as Malaysia has led to the establishment of this study. Therefore, this study aims to investigate and analyze the factors influencing consumers' intention to purchase organic food 
in the developing country-Malaysia. The results from this Malaysian study are similar to the research conducted by [70-72] who studied the factors influencing organic food purchase intention in developing countries, for instance Tanzania, Kenya, and China. Both studies found out that attitude, subjective norm, and self-efficacy are strong and significant predictors of purchase intention towards organic food in the developing countries.

In conclusion, this research revealed that response efficacy and subjective norm were strong predictors of purchase intention towards organic food, both directly and indirectly through attitude, and these results are consistent with the past studies $[30,69,73]$. For the indirect effect, perceived vulnerability and self-efficacy significantly affect purchase intention through attitude and these results are in accordance with the past studies [36,74].

\section{Limitation and Future Research}

This study produced interesting results and verified the integrated model as a good model to forecast consumers' intention to purchase organic food. However, there are some limitations which are significant in this study. Firstly, this study was conducted based on a cross-sectional study and data were collected at a specific point of time. Future research would benefit from a longitudinal approach to data collection as this would allow a more fine-grained study and researchers can observe the pattern of the variables over time. In addition, this study only observes the purchase intention of Malaysian consumers by using a convenience sample which might not represent the general population. Future research could use samples which are more representative of the general population and evaluate similar framework or with different variables in the same purchase intention setting. In terms of product category, no specific product category was considered in this study. Therefore, specific preference and product category could be further investigated in future studies as consumers' awareness about organic food were on the rise. Nevertheless, researchers could consider working in partnership with hypermarkets in order to have higher response rate to questionnaires and smoother process of collecting primary data.

\section{Conclusions}

Although purchase intention towards organic food has been extensively researched, most past studies ignored the influence of perceived threat on purchase intention. This study investigated the relationships by applying TPB and PMT, and it was evident that response efficacy, subjective norm, and attitude towards organic food were the key antecedents that directly affect consumers' purchase intention towards organic food. Additional testing of indirect effects was also performed, and the results revealed that perceived vulnerability, response efficacy, self-efficacy, and subjective norm indirectly influenced consumers' intention to purchase organic food via a mediator, attitude towards organic food. Additionally, response efficacy and subjective norm contributed towards purchase intention, both directly and indirectly. It was also demonstrated that consumers were able to reduce the negative impact of climate change if they would be enthusiastic to consume organic food.

Overall, the findings indicate that social influences and one's belief where organic food consumption will be effective in lessening threats increase people's intention to purchase organic food. The findings also may have some practical implications. Environmental policymakers could leverage on the findings from this study to further promote the production of organic food and demand, by enhancing public's knowledge on organic food through nation-wide awareness campaigns. The findings of this study could also help the government in developing and enlarging the organic production, as well as in developing the policies. As this study found out that response efficacy and subjective norm are the keys factors that influencing consumers to purchase organic food, policymakers can use repetition and promote the benefits of organic food especially in reducing the negative consequences of climate change and health threats, in order to motivate people to perform the target healthy behaviors. 
To conclude, this study provided a comprehensive picture of the antecedents of consumers' purchase intention towards organic food by testing all the hypothesized relationships in the Malaysian context. The outcome provided useful foundation for future studies to investigate the four perceived factors in the non-Western settings. Understanding consumers' attitude and purchase intention could be a valuable research field to undertake in the future.

Author Contributions: The authors worked together for this research. Conceptualization, S.M.P., B.C.T. and T.C.L.; data curation, S.M.P.; formal analysis, S.M.P., B.C.T. and T.C.L.; methodology, S.M.P.; project administration, B.C.T. and T.C.L.; resources, B.C.T. and T.C.L.; software, S.M.P.; supervision, B.C.T. and T.C.L.; validation, T.C.L.; writing—original draft, S.M.P., B.C.T. and T.C.L.; writingreview and editing, S.M.P., B.C.T. and T.C.L. All authors have read and agreed to the published version of the manuscript.

Funding: This research received no external funding.

Institutional Review Board Statement: Not applicable.

Informed Consent Statement: Not applicable.

Data Availability Statement: Not applicable.

Acknowledgments: The authors would like to thank respondents and anonymous reviewers for their precious feedback and comments.

Conflicts of Interest: The authors declare no conflict of interest.

\section{Appendix A}

Table A1. Survey instrument.

\begin{tabular}{|c|c|c|}
\hline Perceived Severity & $\begin{array}{l}\text { PS1 } \\
\text { PS2 } \\
\text { PS3 } \\
\text { PS4 }\end{array}$ & $\begin{array}{l}\text { Climate change is a serious issue. } \\
\text { Climate change will have negative consequences on this planet. } \\
\text { The negative impact of climate change is severe. } \\
\text { The thought of climate change scares me. }\end{array}$ \\
\hline Perceived Vulnerability & $\begin{array}{l}\text { PV1 } \\
\text { PV2 } \\
\text { PV3 } \\
\text { PV4 }\end{array}$ & $\begin{array}{l}\text { Climate change can negatively affect me. } \\
\text { I will experience the negative effects of climate change in my lifetime. } \\
\text { I am vulnerable to the negative effects of climate change. } \\
\text { My chances of being affected negatively by climate change are high. }\end{array}$ \\
\hline Fear & $\begin{array}{l}\text { F1 } \\
\text { F2 } \\
\text { F3 }\end{array}$ & $\begin{array}{l}\text { I fear of getting ill when I exclusively eat agricultural products from } \\
\text { non-organic farming. } \\
\text { I fear products of non-organic farming could contain pesticides residues. } \\
\text { I fear the environment will suffer under current non-organic agricultural practices. }\end{array}$ \\
\hline Intrinsic Rewards & $\begin{array}{l}\text { IR1 } \\
\text { IR2 } \\
\text { IR3 } \\
\text { IR4 }\end{array}$ & $\begin{array}{l}\text { I feel comfortable purchasing non-organic food. } \\
\text { If I purchase non-organic food, I will be healthier. } \\
\text { If I purchase non-organic food, I will be more confident. } \\
\text { If I purchase non-organic food, I will be happier. }\end{array}$ \\
\hline Extrinsic Rewards & $\begin{array}{l}\text { ER1 } \\
\text { ER2 } \\
\text { ER3 } \\
\text { ER4 } \\
\text { ER5 } \\
\text { ER6 } \\
\text { ER7 } \\
\text { ER8 }\end{array}$ & $\begin{array}{l}\text { Non-organic food is easily available. } \\
\text { If I purchase non-organic food, I will save time. } \\
\text { If I purchase non-organic food, I will save money. } \\
\text { If I purchase non-organic food, I will save effort. } \\
\text { If I purchase non-organic food, I will get more acceptances from my peers. } \\
\text { If I purchase non-organic food, I will get more approval from my peers. } \\
\text { If I purchase non-organic food, I will be popular among my peers. } \\
\text { If I purchase non-organic food, I will meet my peers' expectations. }\end{array}$ \\
\hline
\end{tabular}


Table A1. Cont.

\begin{tabular}{|c|c|c|}
\hline \multirow{3}{*}{ Response Efficacy } & RE1 & $\begin{array}{l}\text { I am sure that purchasing organic food is effective in preventing negative } \\
\text { environment effects. }\end{array}$ \\
\hline & RE2 & $\begin{array}{l}\text { I am sure that purchasing organic food will help to prevent depletion of the } \\
\text { scarce resources. }\end{array}$ \\
\hline & RE3 & $\begin{array}{l}\text { I am sure that purchasing organic food will help to prevent threat to my } \\
\text { well-being and the well-being of society. }\end{array}$ \\
\hline \multirow{3}{*}{ Self-efficacy } & SE1 & It is easy for me to be involved in purchases of organic food. \\
\hline & SE2 & If I wanted to, I could easily be involved in purchases of organic food. \\
\hline & SE3 & $\begin{array}{l}\text { It is mostly up to me whether I would like to be involved in purchases of } \\
\text { organic food. }\end{array}$ \\
\hline \multirow{6}{*}{ Response Cost } & $\mathrm{RC} 1$ & $\begin{array}{l}\text { Although organic food is better for my health or the health of my kids or the } \\
\text { environment, I am not willing to pay more for organic food. }\end{array}$ \\
\hline & $\mathrm{RC} 2$ & $\begin{array}{l}\text { I usually compare prices of organic and non-organic food, and will only buy the } \\
\text { organic ones when the price is reasonable to me. }\end{array}$ \\
\hline & RC3 & Organic food is relatively expensive to purchase. \\
\hline & $\mathrm{RC} 4$ & Organic food has limited choices for me. \\
\hline & RC5 & $\begin{array}{l}\text { Purchases of organic food would require too much of an adjustment in my } \\
\text { food consumption. }\end{array}$ \\
\hline & RC6 & There is not enough certainty about the safety of organic food. \\
\hline \multirow{4}{*}{ Subjective Norm } & SN1 & Most people who are important to me think I should purchase organic food. \\
\hline & SN2 & Most people who are important to me would want me to purchase organic food. \\
\hline & SN3 & People whose opinions I value would prefer that I purchase organic food. \\
\hline & SN4 & My friend's positive opinion influences me to purchase organic food. \\
\hline \multirow{3}{*}{ Attitude towards organic food } & AT1 & I like the idea of purchasing organic food. \\
\hline & AT2 & Purchasing organic food is a good idea. \\
\hline & AT3 & I have a favourable attitude toward purchasing organic food. \\
\hline \multirow{5}{*}{ Purchase Intention } & PI1 & $\begin{array}{l}\text { I will consider buying organic food because they are less polluting in } \\
\text { coming times. }\end{array}$ \\
\hline & PI2 & I will consider switching to organic food for ecological reasons. \\
\hline & PI3 & I plan to spend more on organic food rather than non-organic food. \\
\hline & PI4 & $\begin{array}{l}\text { I expect to purchase organic food in the future because of its positive } \\
\text { environmental contribution. }\end{array}$ \\
\hline & PI5 & I definitely want to purchase organic food in the near future. \\
\hline
\end{tabular}

\section{References}

1. Perez-Barea, J.J.; Espantaleon-Perez, R.; Sedik, P. Evaluating the Perception of Socially Responsible Consumers: The Case of Products Derived from Organic Beef. Sustainability 2020, 12, 10166. [CrossRef]

2. United Nations Development Programme (UNDP). Goal 13: Climate Action; UNDP: New York, NY, USA, 2020.

3. Chen, M.F. Attitude Toward Organic Foods Among Taiwanese as Related to Health Consciousness, Environmental Attitudes, and the Mediating Effects of a Healthy Lifestyle. Br. Food J. 2009, 111, 165-177. [CrossRef]

4. Janssen, M. Determinants of Organic Food Purchases: Evidence from Household Panel Data. Food Qual. Prefer. 2018, 68, 19-28. [CrossRef]

5. Kim, S.; Jeong, S.H.; Hwang, Y. Predictors of Pro-Environmental Behaviors of American and Korean Students: The Application of the Theory of Reasoned Action and Protection Motivation Theory. Sci. Commun. 2012, 35, 168-188. [CrossRef]

6. Lockie, S.; Lyons, K.; Lawrence, G.; Grice, J. Choosing Organics: A Path Analysis of Factors Underlying the Selection of Organic Food Among Australian Consumers. Appetite 2004, 43, 135-146. [CrossRef]

7. Park, O.H.; Hoover, L.; Dodd, T.; Huffman, L.; Feng, D. The Use of the Modified Protection Motivation Theory to Explore Adult Consumers' Functional Foods Consumption Behavior. In Proceedings of the 16th Graduate Student Research Conference in Hospitality and Tourism Houston, University of Massachusetts Amherst Community, Houston, TX, USA, 6-8 January2011; pp. 1-15.

8. TechSci Research. Global Organic Food Market by Product Type (Organic Meat, Poultry and Dairy; Organic Fruits and Vegetables; Organic Processed Food; etc.), by Region (Europe, North America, Asia-Pacific, etc.), Competition Forecast and Opportunities, 2012-2022; TechSci Research: New York, NY, USA, 2017.

9. Malaysian Agricultural Research and Development Institute (MARDI). Scope of Research—Organic Farming; MARDI: Seri Kembangan, Malaysia, 2020. 
10. Somasundram, C.; Zuliana, R.; Vicknesha, S. A Review on Organic Food Production in Malaysia. Horticulturae 2016, 2, 12. [CrossRef]

11. Willer, H.; Lernoud, J. The World of Organic Agriculture: Statistics E Emerging Trends 2019; Research Institute of Organic Agriculture (FiBL) and IFOAM: Nurnberg, Germany, 2019.

12. Chait, J. The Balance Small Business. What is Organic Farming? Available online: https://www.thebalancesmb.com/thedefinition-of-organic-farming-2538081 (accessed on 1 May 2020).

13. Coleman, L.J.; Bahnan, N.; Kelkar, M.; Curry, N. Walking the Talk: How the Theory of Reasoned Action Explains Adult and Student Intentions to Go Green. J. Appl. Bus. Res. 2011, 27, 107-116. [CrossRef]

14. Rogers, R.W. A Protection Motivation Theory of Fear Appeals and Attitude Change. J. Psychol. Interdiscip. Appl. 1975, 91, 93-114. [CrossRef]

15. Keshavarz, M.; Karami, E. Farmers' Pro-Environmental Behavior Under Drought: Application of Protection Motivation Theory. J. Arid Environ. 2016, 127, 128-136. [CrossRef]

16. Mirkarimi, K.; Mostafavi, F.; Eshghinia, S.; Vakili, M.A.; Ozouni-Davaji, R.B.; Aryaie, M. Effect of Motivational Interviewing on a Weight Loss Program Based on the Protection Motivation Theory. Iran. Red Crescent Med. J. 2015, 17, 1-8. [CrossRef]

17. Cismaru, M.; Cismaru, R.; Ono, T.; Nelson, K. Act on climate change: An application of Protection Motivation Theory. Soc. Mark. Q. 2011, 17, 62-84. [CrossRef]

18. Chung, H.; Ahn, E.; Kang, S. Processing Anti-Smoking Ads Among College Students: The Role of Emotional Response and Level of Smoking. J. Promot. Manag. 2016, 22, 370-385. [CrossRef]

19. Cox, D.N.; Koster, A.; Russell, C.G. Predicting Intentions to Consumer Functional Foods and Supplements to Offset Memory Loss Using an Adaptation of Protection Motivation Theory. Appetite 2004, 43, 55-64. [CrossRef] [PubMed]

20. Hsieh, H.L.; Kuo, Y.M.; Wang, S.R.; Chuang, B.K.; Tsai, C.H. A Study of Personal Health Record User's Behavioral Model Based on the PMT and UTAUT Integrative Perspective. Int. J. Environ. Reserach Public Health 2017, 14, 8. [CrossRef]

21. Janmaimool, P. Application of Protection Motivation Theory to Investigate Sustainable Waste Management Behaviors. Sustainability 2017, 9, 1079. [CrossRef]

22. Milne, S.; Sheeran, P.; Orbell, S. Prediction and Intervention in Health-Related Behavior: A Meta-Analytic Review of Protection Motivation Theory. J. Appl. Soc. Psychol. 2000, 30, 106-143. [CrossRef]

23. Nguyen, Q.A.; Hens, L.; MacAlister, C.; Johnson, L.; Lebel, B.; Tan, S.B.; Nguyen, H.M.; Nguyen, N.T.; Lebel, L. Theory of Reasoned Action as a Framework for Communicating Climate Risk: A Case Study of Schoolchildren in the Mekong Delta in Vietnam. Sustainability 2018, 10, 2019. [CrossRef]

24. Xiao, A.; Yang, S.; Iqbal, Q. Factors Affecting Purchase Intentions in Generation Y: An Empirical Evidence from Fast Food Industry in Malaysia. Adm. Sci. 2019, 9, 4. [CrossRef]

25. Bai, L.; Wang, M.; Gong, S. Understanding the Antecedents of Organic Food Purchases: The Important Roles of Beliefs, Subjective Norms, and Identity Expressiveness. Sustainability 2019, 11, 3045. [CrossRef]

26. Baghiani-Moghadam, M.H.; Andi, S.J.; Shirvani, J.S.; Khafri, S.; Ghadimi, R.; Parsian, H. Efficiency of Two Constructs Called "Fear of Disease" and "Perceived Severity of Disease" on the Prevention of Gastric Cancer: Application of Protection Motivation Theory. Casp. J. Intern. Med. 2015, 6, 201-208.

27. Gebrehiwot, T.; Veen, A.V. Farmers Prone to Drough Risk: Why some Farmers Undertake Farm-Level Risk-Reduction Measures While Others Not? Environ. Manag. 2015, 55, 588-602. [CrossRef] [PubMed]

28. Rainear, A.M.; Christensen, J.L. Protection Motivation Theory as an Explanatory Framework for Proenvironmental Behavioral Intentions. Commun. Res. Rep. 2017, 34, 239-248. [CrossRef]

29. Moeini, B.; Ezati, E.; Barati, M.; Shahkolai, F.R.; Mezerji, N.M.; Afshari, M. Skin Cancer Preventive Behaviors in Iranian Farmers. Workplace Health Saf. 2019, 67, 231-240. [CrossRef]

30. Ruthig, J.C. Health Risk Perceptions and Exercise in Older Adulthood: An Application of Protection Motivation Theory. J. Appl. Gerontol. 2016, 35, 939-959. [CrossRef]

31. Verkoeyen, S.; Nepal, S.K. Understanding Scuba Divers' Response to Coral Bleaching: An Application of Protection Motivation Theory. J. Environ. Manag. 2019, 231, 869-877. [CrossRef]

32. Hassandoust, F.; Techatassanasoontorn, A.A. Understanding Users' Information Security Awareness and Intentions: A Full Nomology of Protection Motivation Theory. In Cyber Influence and Cognitive Threats; Benson, V., Mcalaney, J., Eds.; Elsevier Inc.: London, UK, 2020; pp. 129-143.

33. Ling, M.; Kothe, E.J.; Mullan, B.A. Predicting Intention to Receive a Seasonal Influenza Vaccination Using Protection Motivation Theory. Soc. Sci. Med. 2019, 233, 87-92. [CrossRef] [PubMed]

34. Scarpa, R.; Thiene, M. Organic Food Choices and Protection Motivation Theory: Addressing the Psychological Sources of Heterogeneity. Food Qual. Prefer. 2011, 22, 532-541. [CrossRef]

35. Bandura, A. Self-Efficacy Mechanism in Human Agency. Am. Psychol. 1982, 37, 122-147. [CrossRef]

36. Ajzen, I. Perceived Behavioural Control, Self-Efficacy, Locus of Control, and the Theory of Planned Behavior. J. Appl. Soc. Psychol. 2002, 32, 665-683. [CrossRef]

37. Wang, Y.; Liang, J.; Yang, J.; Ma, X.; Li, X.; Wu, J.; Yang, G.; Ren, G.; Feng, Y. Analysis of the Environmental Behavior of Farmers for Non-Point Source Pollution Control and Management: An Integration of the Theory of Planned Behavior and the Protection Motivation Theory. J. Environ. Manag. 2019, 237, 15-23. [CrossRef] 
38. Aung, Y.M.; Chotiyaputta, V. Exploring Customers' Purchase Intention on Poultry Products Using Protection Motivation Theory. Panyapiwat J. 2020, 12, 145-165.

39. Aertsens, J.; Verbeke, W.; Mondelaers, K.; Huylenbroeck, G.V. Personal Determinants of Organic Food Consumption: A Review. Br. Food J. 2009, 111, 1140-1167. [CrossRef]

40. Chu, K.M. Mediating Influences of Attitude on Internal and External Factors Influencing Consumers' Intention to Purchase Organic Foods in China. Sustainability 2018, 10, 4690. [CrossRef]

41. Ostrom, T.M. The Relationship Between the Affective, Behavioral, and Cognitive Components of Attitude. J. Exp. Soc. Psychol. 1969, 5, 12-30. [CrossRef]

42. Chyung, S.Y.; Roberts, K.; Swanson, I.; Hankinson, A. Evidence-Based Survey Design: The Use of a Midpoint on the Likert Scale. Perform. Improv. 2017, 56, 15-23. [CrossRef]

43. Ibrahim, H.; Al-Ajlouni, M.M. Sustainable Consumption: Insights from the Protection Motivation (PMT), Deontic Justice (DJT) and Construal Level (CLT) Theories. Manag. Decis. 2018, 56, 610-633. [CrossRef]

44. Wu, W.Y.; Linn, C.T.; Fu, C.S.; Sukoco, B.M. The Role of Endorsers, Framing, and Rewards on the Effectiveness of Dietary Supplement Advertisements. J. Health Commun. Int. Perspect. 2012, 17, 54-75. [CrossRef]

45. Abdullah, I. Advertising in Malaysia. In More Advertising Worldwide; Kloss, I., Ed.; Springer Science \& Business Media: Stralsund, Germany, 2002; pp. 159-181.

46. Anvar, M.; Venter, M. Attitudes and Purchase Behaviour of Green Products Among Generation Y Consumers in South Africa. Mediterr. J. Soc. Sci. 2014, 5, 183-194. [CrossRef]

47. de-Magistris, T.; Gracia, A. Consumers' Willingness-to-Pay for Sustainable Food Products: The Case of Organically and Locally Grown Almonds in Spain. J. Clean. Prod. 2016, 118, 97-104. [CrossRef]

48. Maloney, J.; Lee, M.-Y.; Jackson, V.; Miller-Spillman, K.A. Consumer Willingness to Purchase Organic Products: Application of the Theory of Planned Behavior. J. Glob. Fash. Mark. 2014, 5, 308-321. [CrossRef]

49. Lee, J.; Modi, A.; Patel, J. Predicting Green Product Consumption Using Theory of Planned Behavior and Reasoned Action. J. Retail. Consum. Serv. 2016, 29, 123-134. [CrossRef]

50. Tan, B.C.; Lau, T.C. Green Purchase Behavior: Examining the Influence of Green Environmental Attitude, Perceived Consumer Effectiveness and Specific Green Purchase Attitude. Aust. J. Basic Appl. Sci. 2011, 5, 559-567.

51. Yadav, R. Altruistic or Egoistic: Which Value Promotes Organic Food Consumption Among Young Consumers? A Study in the Context of a Developing Nation. J. Retail. Consum. Serv. 2016, 33, 92-97. [CrossRef]

52. Chin, W.W. Commentary: Issues and Opinion on Structural Equation Modeling. MIS Q. 1998, 22, VII-XVI.

53. Erdfelder, E.; Faul, F.; Buchner, A. GPOWER: A General Power Analysis Program. Behav. Res. Methods Instrum. Comput. 1996, 28, 1-11. [CrossRef]

54. Goodhue, D.L.; Lewis, W.; Thompson, R. Does PLS Have Advantages for Small Sample Size or Non-Normal Data? MIS Q. 2012, 36, 981-1001. [CrossRef]

55. Hair, J.F.; Black, W.C.; Babin, B.J.; Anderson, R.E. Confirmatory Factor Analysis. In Multivatiate Data Analysis, 7th ed.; Pearson Education Limited: Harlow, UK, 2014; pp. 599-638.

56. Hair, J.F.; Ringle, C.M.; Sarstedt, M. PLS-SEM: Indeed a Silver Bullet. J. Mark. Theory Pract. 2011, 19, 139-152. [CrossRef]

57. Anderson, J.C.; Gerbing, D.W. Structural Equation Modeling in Practice: A Review and Recommended Two-Step Approach. Psychol. Bull. 1988, 103, 411-423. [CrossRef]

58. Cronbach, L.J. Coefficient Alpha and the Internal Structure of Tests. Psychometrika 1951, 16, 297-334. [CrossRef]

59. Nunnally, J. Psychometric Theory, 2nd ed.; McGraw-Hill: New York, NY, USA, 1978.

60. Fornell, C.; Larcker, D.F. Evaluating structural equation models with unobservable variables and measurement error. J. Mark. Res. 1981, 18, 39-50. [CrossRef]

61. Kline, R.B. Principles and Practice of Structural Equation Modeling, 4th ed.; Guilford Publications: New York, NY, USA, 2015.

62. Gold, A.H.; Malhotra, A.; Segars, A.H. Knowledge Management: An Organizational Capabilities Perspective. J. Manag. Inf. Syst. 2001, 18, 185-214. [CrossRef]

63. Hair, J.F.; Hult, G.T.; Ringle, C.M.; Sarstedt, M. A Primer on Partial Least Squares Structural Equation Modeling (PLS-SEM), 2nd ed.; SAGE Publications: Thousand Oaks, CA, USA, 2016.

64. Cohen, J. Statistical Power Analysis for the Behavioral Sciences, 2nd ed.; Lawrence Erlbaum Associates: New York, NY, USA, 1988.

65. Fornell, C.; Cha, J. Partial Least Squares. In Advanced Methods of Marketing Research; Bagozzi, R.P., Ed.; Blackwell Publishers: Cambridge, MA, USA, 1994; pp. 52-78.

66. UN News. Fall in COVID-Linked Carbon Emissions Won't Halt Climate Change-UN Weather Agency Chief; UN News: New York, NY, USA, 2020.

67. Henson, S.; Cranfield, J.; Herath, D. Understanding Consumer Receptivity Towards Foods and Non-Prescription Pills Containing Phytosterols as a Means to Offset the Risk of Cardiovascular Disease: An Application of Protection Motivation Theory. Int. J. Consum. Stud. 2010, 34, 28-37. [CrossRef]

68. Sharma, N.; Dayal, R. Drivers of Green Purchase Intentions: Green Self-Efficacy and Perceived Consumer Effectiveness. Glob. J. Enterp. Inf. Syst. 2016, 8, 27-32. [CrossRef]

69. Maichum, K.; Parichatnon, S.; Peng, K.C. Application of the Extended Theory of Planned Behavior model to Investigate Purchase Intention of Green Products Among Thai Consumers. Sustainability 2016, 8, 1077. [CrossRef] 
70. Wang, X.; Pacho, F.; Liu, J.; Kajungiro, R. Factors Influencing Organic Food Purchase Intention in Developing Countries and the Moderating Role of Knowledge. Sustainability 2019, 11, 209. [CrossRef]

71. Li, S.; Jaharuddin, N.S. Identifying the Key Purchase Factors for Organic Food Among Chinese Consumers. Front. Bus. Res. China 2020, 14, 1-23. [CrossRef]

72. Pacho, F. What Influences Consumers to Purchase Organic Food in Developing Countries? Br. Food J. 2020, 122, 1-15. [CrossRef]

73. Andrighetto, G.; Grieco, D.; Tummolin, L. Perceived Legitimacy of Normative Expectations Motivates Compliance with Social Norms when Nobody is Watching. Front. Psychol. 2015, 6, 1-17. [CrossRef]

74. Luu, V.; Land, L.; Chin, W.W. Safeguarding Against Romance Scams -Using Protection Motivation Theory. In Proceedings of the 25th European Conference on Information Systems (ECIS), Association for Information Systems Electronic Library (AISeL), Guimarães, Portugal, 10 June 2017; pp. 2429-2444. 